Disponible en ligne sur

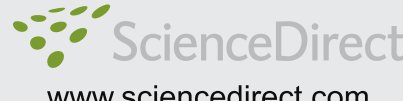

www.sciencedirect.com
Elsevier Masson France

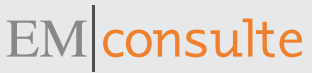

www.em-consulte.com

ORIGINAL ARTICLE

\title{
Effects of three different water temperatures on dehydration in competitive swimmers
}

\section{Effets de trois différentes valeurs de température de l'eau sur la déshydratation chez des nageurs de compétition}

\section{F. Macaluso ${ }^{a, *, b}$, V. Di Felice ${ }^{b}$, G. Boscaino ${ }^{c}$, G. Bonsignore ${ }^{d}$, T. Stampone ${ }^{e}$, F. Farina ${ }^{b}$, G. Morici ${ }^{f}$}

\author{
a Department of Physiological Science, Stellenbosch University, clo Merriman \& Bosman Road, Mike de Vries Building, \\ Stellenbosch, 7600 South Africa \\ b Department of Experimental Medicine (Di.Me.S.), Section of Human Anatomy "E. Luna", University of Palermo, Palermo, Italy \\ " Department of Statistics and Mathematics "S. Vinelli", University of Palermo, Palermo, Italy \\ 'Laboratory of Transfusion Medicine, Hospital "Villa Sofia - CTO", Palermo, Italy \\ e Laboratory of Clinical Pathology, Hospital "Villa Sofia - CTO", Palermo, Italy \\ ${ }^{f}$ Department of Experimental Medicine (Di.Me.S.), Section of Human Physiology, University of Palermo, Palermo, Italy
}

Received 5 May 2009; accepted 5 October 2010

Available online 20 January 2011

\section{KEYWORDS}

Open water;

Swimming;

Sweat rate;

Fluid balance;

Performance;

Rectal temperature

\begin{abstract}
Summary
Aims. - The purpose of this study was to evaluate the effects of three different water temperatures on physiological responses (dehydration, sweat rate, urine output, rectal temperature and plasma electrolytes) of competitive athletes during a "simulated" race of $5 \mathrm{~km}$ in an indoor swimming pool.

Methods. - Nine male competitive master swimmers swam $5 \mathrm{~km}$ with the water at temperatures of 23,27 and $32{ }^{\circ} \mathrm{C}$. Immediately before (Pre) and after (Post) each trial, samples of blood and urine were collected, body weight was recorded and rectal temperature was measured. The dehydration percentage and sweat rate were the highest at $32^{\circ} \mathrm{C}$ and the lowest at $23^{\circ} \mathrm{C}\left(23^{\circ} \mathrm{C}\right.$ : $-0.9 \pm 0.5 ; 27^{\circ} \mathrm{C}:-1.3 \pm 0.6 ; 32^{\circ} \mathrm{C}:-2.2 \pm 0.7 \%$ and $23^{\circ} \mathrm{C}: 0.48 \pm 0.28 ; 27^{\circ} \mathrm{C}: 0.76 \pm 0.36$; $\left.32^{\circ} \mathrm{C}: 1.25 \pm 0.37 \mathrm{l} / \mathrm{h}\right)$. The Post urine volume output was not significantly different in the three trials $\left(23^{\circ} \mathrm{C}: 122.6 \pm 62.4 ; 27^{\circ} \mathrm{C}: 78.2 \pm 24.9 ; 32^{\circ} \mathrm{C} 81.4 \pm 37.0 \mathrm{~mL}\right)$. The 27 and $32^{\circ} \mathrm{C}$ water increased the rectal temperature (Pre: $37.0 \pm 0.3$; Post: $37.9 \pm 0.5^{\circ} \mathrm{C}$-Pre: $36.9 \pm 0.4$; Post: $38.0 \pm 0.4^{\circ} \mathrm{C}$, respectively).
\end{abstract}

\footnotetext{
* Corresponding author.

E-mail addresses: macalusof@sun.ac.za, filippo.mac@libero.it (F. Macaluso).
} 
Results. - This study shows that dehydration, sweat rate and body temperatures simultaneously increase with the rise of water temperature during the shortest open water swimming event distance $(5 \mathrm{~km})$ performed at race intensity.

(c) 2010 Elsevier Masson SAS. All rights reserved.

\section{MOTS CLÉS}

Natation ;

Taux de sudation ;

Équilibre ;

Hydroélectrolytique ;

Performance ;

Température rectale

\section{Résumé}

Objectifs. - Évaluer les effets de trois températures différentes de l'eau sur les réponses physiologiques (déshydratation, sudation, volume urinaire, température rectale et électrolytes plasmatiques) chez des athlètes de compétition, à l'issue d'une course «simulée» de $5 \mathrm{~km}$ dans une piscine couverte.

Méthodes. - Neuf nageurs de compétition (masculins) ont nagé $5 \mathrm{~km}$ dans une eau à des températures respectivement de 23,27 et $32^{\circ} \mathrm{C}$. Immédiatement avant (Pre) et après (Post) chaque épreuve, des échantillons de sang et d'urine ont été prélevés, la masse corporelle et la température rectale ont été mesurées. Le pourcentage de déshydratation et le taux de sudation étaient le plus élevés dans l'eau à $32^{\circ} \mathrm{C}$ et le plus bas dans l'eau à $23^{\circ} \mathrm{C}\left(23^{\circ} \mathrm{C}\right.$ : $-0,9 \pm 0,5 ; 27^{\circ} \mathrm{C}:-1,3 \pm 0,6 ; 32^{\circ} \mathrm{C}:-2,2 \pm 0,7 \%$ et $23^{\circ} \mathrm{C}: 0,48 \pm 0,28 ; 27^{\circ} \mathrm{C}: 0,76 \pm 0,36$; $\left.32^{\circ} \mathrm{C}: 1,25 \pm 0,37 \mathrm{~L} / \mathrm{h}\right)$. Le volume urinaire mesuré après l'effort (Post) n'était pas significativement différent dans les trois cas $\left(23^{\circ} \mathrm{C}: 122,6 \pm 62,4 ; 27^{\circ} \mathrm{C}: 78,2 \pm 24,9 ; 32^{\circ} \mathrm{C} 81,4 \pm 37,0 \mathrm{~mL}\right)$. L'eau à 27 et $32^{\circ} \mathrm{C}$ a augmenté la température rectale (Pre : $37,0 \pm 0,3$; Post : $37,9 \pm 0,5^{\circ} \mathrm{C}-$ Pre : $36,9 \pm 0,4$; Post: $38,0 \pm 0,4^{\circ} \mathrm{C}$, respectivement).

Résultats. - Cette étude montre que la déshydratation, le taux de sudation et la température corporelle augmentent simultanément avec la température de l'eau, au cours de la plus courte des distances parcourues lors de compétitions de nage en eau libre, effectuée avec un effort d'intensité comparable à celui d'une course.

(c) 2010 Elsevier Masson SAS. Tous droits réservés.

\section{Introduction}

Open water swimming is defined, by the Fédération Internationale de Natation (FINA), as any swimming event that takes place in a body of water such as rivers, lakes or oceans [1]. Open water swimming world championships are performed on distances of 5, 10 and $25 \mathrm{~km}$. During the shortest $(5 \mathrm{~km})$ distance events swimmers are not permitted to consume food and drink. Open water swimmers perform races in a wide range of environmental conditions, such as cold/hot water temperature, high/low water salinity, high/low altitudes and high/low wave height. Hypothermia and dehydration are the most common medical problems during open water events [2,3]. Open water swimming is a widespread aquatic sport performed also by the master swimmers globally [4].

Exercise in cold water results in a rapid cooling of the body, because thermal conductivity is approximately 25 times more than in air [5], and in a raised oxygen uptake as a consequence of shivering thermogenesis effect [6]. The increase of water temperature and exercise intensity induces a rise of body temperature [7], although, the heat exchange occurs mainly via conduction and convection, substantial amounts of fluid may be lost as sweat during water sport [8]. Soler et al. [9] reported that during a typical interval training $(9 \mathrm{~km})$ in an outdoor pool (water temperature: $\left.27^{\circ} \mathrm{C}\right)$, the magnitude of fluid losses $(1.8 \mathrm{~kg}$, i.e. $2.5 \%$ of body weight) was sufficient to compromise convective thermoregulation because of the decreased plasma volume $(10.5 \%)$, although the swimmers drank ad libitum. Therefore, if a negative body fluid balance compromises the thermoregulatory and physiological response during swimming training, this effect may be emphasized during an endurance swimming event. The hypothesis of the present study was that athletes, swimming the shortest open water swimming world championship event distance $(5 \mathrm{~km})$ without food or drink supplementation as indicated by FINA rules, may have severe negative body fluid balance in warm water.

The purpose of this study was to evaluate the effects of three different water temperatures $\left(23,27\right.$ and $32{ }^{\circ} \mathrm{C}$ ) on physiological responses (dehydration, sweat rate, urine output, rectal temperature, plasma electrolytes and fluid balance) to a "simulated" race of $5 \mathrm{~km}$ in competitive athletes in an indoor swimming pool ( $25 \mathrm{~m}$ long).

\section{Methods}

\subsection{Subjects}

Nine volunteer male competitive master swimmers, ranked in the top 5 of category in open water $(1.5-10 \mathrm{~km})$ Italian races, were studied (age: $34.6 \pm 14.4$ years, height: $172.1 \pm 9.8 \mathrm{~cm}$, mass: $72.7 \pm 8.5 \mathrm{~kg}$, body fat: $12.7 \pm 3.5 \%$, body surface area: $\left.1.86 \pm 0.16 \mathrm{~m}^{2}\right)$. The subjects trained five to six times per week (3-8 km per training session) in 25- and 50-meter swimming pools (water temperature about $27^{\circ} \mathrm{C}$ ). Participants were informed of the experimental procedures and associated risk before having to provide a written informed consent form. This study was approved by the institutional review board for the protection of human subjects of the University of Palermo.

\subsection{Protocol}

During this study, subjects completed three experimental trials, separated by 7 days, in a 25 -meter indoor swimming pool; they swam $5 \mathrm{~km}$ with water at the temperatures of 23 , 
Table 1 Ambient and water characteristics for each trial.

\begin{tabular}{|c|c|c|c|c|c|}
\hline \multirow[b]{2}{*}{ Trial $\left({ }^{\circ} \mathrm{C}\right)$} & \multicolumn{2}{|l|}{ Ambient } & \multicolumn{2}{|l|}{ Water } & \multirow[b]{2}{*}{$\mathrm{pH}$} \\
\hline & Temperature $\left({ }^{\circ} \mathrm{C}\right)$ & Relative humidity (\%) & Temperature $\left({ }^{\circ} \mathrm{C}\right)$ & Chlorine (mg/L) & \\
\hline 23 & $30.1 \pm 1.3$ & $74 \pm 3$ & $23.3 \pm 0.3$ & 1.2 & 7.29 \\
\hline 27 & $27.8 \pm 1.0$ & $82 \pm 5$ & $26.8 \pm 0.2$ & 1.1 & 7.28 \\
\hline 32 & $28.5 \pm 1.3$ & $73 \pm 2$ & $32.0 \pm 0.4$ & 1.5 & 7.46 \\
\hline
\end{tabular}

27 and $32^{\circ} \mathrm{C}$. The swimming speed of all athletes in each trial was as close as possible to their personal lactate threshold speed (data not shown), considered as the swimming speed at which an athlete produced $4 \mathrm{mmol} / \mathrm{L}$ lactate in the blood. Data were obtained by the swimming club coach. The water temperatures of the trials were based on Galbo et al. [6], although the coldest trial was set at $23^{\circ} \mathrm{C}$ and not at $22^{\circ} \mathrm{C}$, this was due to environmental conditions. The order of the trials was decided randomly and it was: 23,32 and $27^{\circ} \mathrm{C}$. Food and fluid were not provided before and during each trial. Throughout the course of this study, the subjects were instructed: to consume their regular diet and to repeat a similar food intake 3 days before each trial; to maintain their usual training routine and to abstain from vigorous exercise for at least $24 \mathrm{~h}$ before each trial.

The water and ambient characteristics of each trial are reported in Table 1 . This study was designed in the way that all subjects completed the same trial in the same day, as they started together a race with the purpose to simulate the physiological responses of a race [10]. The athletes raced in side-by-side swimming pool lanes. Furthermore, each athlete was free to determine his own swimming pace during the trials, as in the event of a normal race, with the purpose to have the specific physiological response of a race. Although no verbal encouragement was given during the trials by the investigators, before the trials swimmers were boastful of who would finish with the best time, which served as motivation.

\subsection{Measurements}

The subjects came to the laboratory at 7:00 am of each test day following an overnight fast (at least 8 hours after the last drink and meal). First of all, to the subjects were asked to urinate, and the urine samples were used to measure the urine specific gravity (USG). Then, they were weighed to the nearest $25 \mathrm{~g}$ (all body weight measurements were taken with the subjects wearing swimsuit only-Seca 710, Hamburg, Germany). After an equilibration time of $15 \mathrm{~min}$ in a sitting posture, blood was drawn from the antecubital vein to determine haemoglobin $(\mathrm{Hgb})$, hematocrit $(\mathrm{Hct})$, sodium $\left(\mathrm{Na}^{+}\right)$, potassium $\left(\mathrm{K}^{+}\right)$, magnesium $\left(\mathrm{Mg}^{++}\right)$concentrations. Immediately (approximately $60 \mathrm{~s}$ on pool deck) before (Pre) each trial, rectal and axillary temperatures $\left(T_{r e}\right.$ and $T_{a x}$, respectively) [11] were measured with traditional mercury thermometers set by a medical doctor (rectal thermometer was inserted $3 \mathrm{~cm}$ past the external anal sphincter for $3 \mathrm{~min}$; axillary thermometer was inserted in axillary fossa for $5 \mathrm{~min}$ [12]). Core temperature was not measured.

Immediately (approximately $60 \mathrm{~s}$ on pool deck) after (Post) each trial, rectal and axillary temperatures were mea- sured again. Then, the urines were collected to measure USG and total urine volume. The subjects were weighed again at the end of each trial, after being dried, to measure dehydration percentage. Then, the subjects were asked to sit for $15 \mathrm{~min}$ and the Post blood samples were drawn. Only at the end of each experimental trial the subjects were allowed to eat and drink.

The blood and urine measurements were performed by the hematology laboratory of "Azienda Ospedaliera Villa Sofia-CTO Palermo"' with automated analyzers for blood (Sysmex XE2100, DASIT, Milan, Italy; Dimension RxL Dade Behring Inc., Newark, DE) and urine samples (Aution Max AX4280, A. Menarini Dignostics, Florence, Italy; Sysmex UF100, DASIT, Milan, Italy). Percentage changes in plasma and red cell volume, at the end of the three trials, were calculated using Hct and Hgb concentrations, according to Dill and Costill [13].

The chronometric time to swim the $5 \mathrm{~km}$ and split times $(100 \mathrm{~m})$ was recorded to evaluate the performance. Sweat rate was calculated using the difference between pre- and post-exercise body weight divided by the length of trial; it was not adjusted for body surface area, weight losses associated with energy metabolism or respiratory fluid losses [14].

\subsection{Statistics}

A two-way ANOVA for repeated measures was performed: swimming exercise (Pre and Post) versus water temperature $\left(23,27\right.$ and $\left.32^{\circ} \mathrm{C}\right)$. If no interaction but just singular effect was detected, a one-way ANOVA was performed: this case concerned urine volume, sweat rate, performance, body mass loss, plasma and red cell volume. If a significant difference was detected during one- or two-way ANOVA analyses, this was further evaluated by post hoc Duncan's multiple-range test (Duncan's MRT) to determine the ranking of trial conditions, based on the estimations of the effects on the variable. The statistical significance was declared when $P<0.05$. The data are expressed as means \pm SD. All statistical procedures were performed using SAS (SAS Institute Inc. 1991).

\section{Results}

\subsection{Body mass change}

In all trials, body mass and sweat rate were lost with the magnitude of these losses being graded by the water temperatures (Fig. 1). 

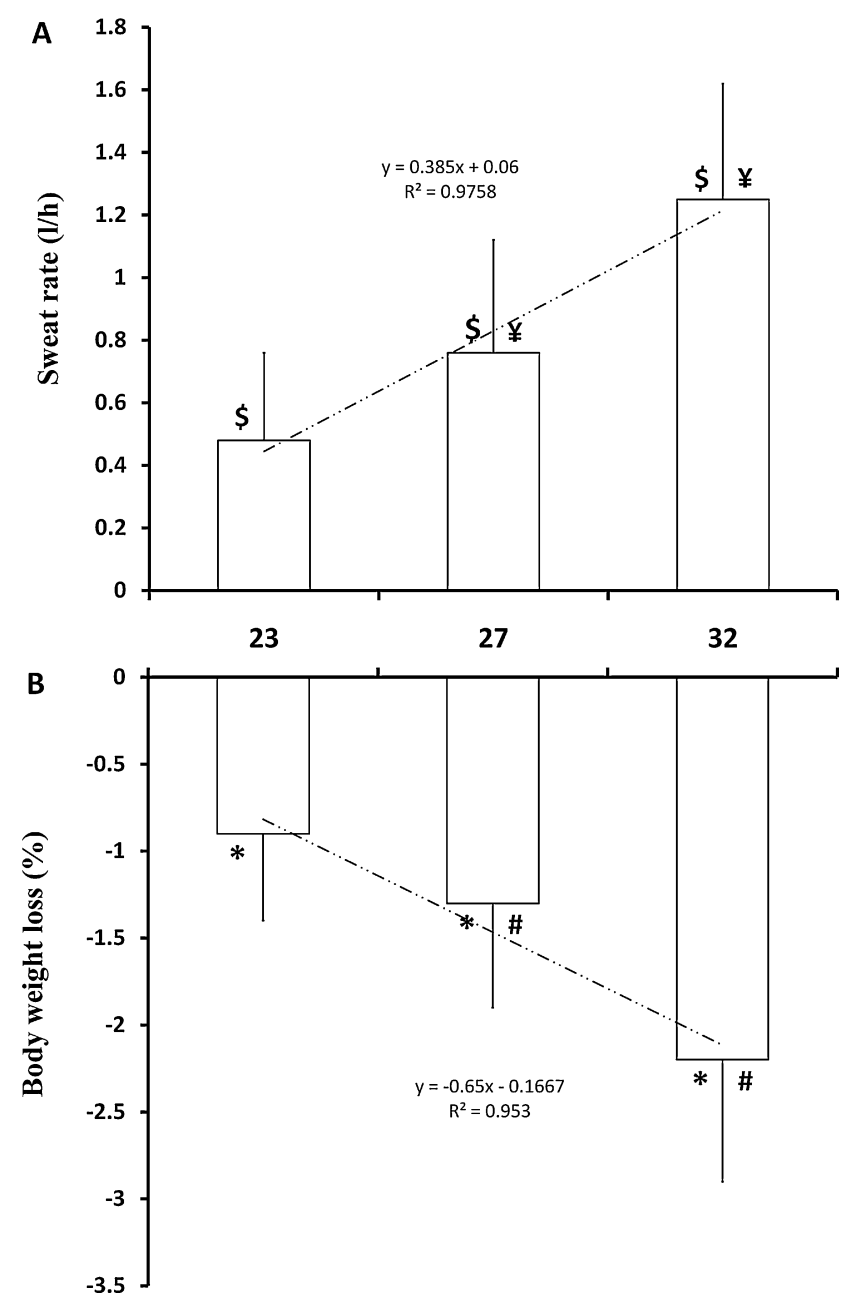

Figure 1 Hydration status: sweat rate (A) and body weight loss $(B)$ in response to water temperature. The values are expressed as means \pm SD. Differences between data sets with the same symbol are significant $(P<0.05)$. The dotted lines indicate the trendlines for sweat rate and bodyweight.

\subsection{Urine output}

The Post urine volume output was not significantly different in the three trials $\left(23^{\circ} \mathrm{C}\right.$ : $122.6 \pm 62.4 ; 27^{\circ} \mathrm{C}$ : $\left.78.2 \pm 24.9 ; 32^{\circ} \mathrm{C} 81.4 \pm 37.0 \mathrm{~mL}\right)$. The Post USG concentration decreased in the $23^{\circ} \mathrm{C}$ (Pre: $1.021 \pm 0.006$; Post: $1.018 \pm 0.010 \mathrm{~g} / \mathrm{mL}$ ) trial and increased in both 27 (Pre: $1.019 \pm 0.005$; Post: $1.021 \pm 0.004 \mathrm{~g} / \mathrm{mL}$ ) and $32^{\circ} \mathrm{C}$ trials
(Pre: $1.019 \pm 0.005$; Post: $1.021 \pm 0.004 \mathrm{~g} / \mathrm{mL}$ ). The highest USG concentration was recorded after the $32^{\circ} \mathrm{C}$ trial but the difference did not reach statistical significance by Duncan's MRT.

\subsection{Rectal and axillary temperature}

The measurements of rectal and axillary temperature Pre and Post trial for each condition are shown in Table 2 . The Post $\mathrm{T}_{\text {re }}$ in the 27 and $32^{\circ} \mathrm{C}$ trials was significantly higher than the other $\mathrm{T}_{\text {re }}$ recorded during the experiment; and the Pre and Post $\mathrm{T}_{\text {re }}$ were similar in the $23^{\circ} \mathrm{C}$ trial. The Post $\mathrm{T}_{\mathrm{ax}}$ was significantly higher in the $32^{\circ} \mathrm{C}$ trial than in the other $\mathrm{T}_{\mathrm{ax}}$ recorded during the experiment, and the Pre and Post $\mathrm{T}_{\mathrm{ax}}$ were similar in the 23 and $27^{\circ} \mathrm{C}$ trials.

\subsection{Plasma electrolytes}

The Post plasma $\mathrm{Na}^{+}$concentration in the $32^{\circ} \mathrm{C}$ trial was significantly higher than the other $\mathrm{Na}^{+}$concentration recorded during the experiment. The Pre and Post $23^{\circ} \mathrm{C}$ and the Post $32^{\circ} \mathrm{C}$ plasma $\mathrm{Na}^{+}$concentration were significantly higher than in Pre and Post $27^{\circ} \mathrm{C}$. Statistically analysis indicated a main effect of swimming exercise on plasma $\mathrm{Mg}^{++}$concentration, and the main effect of water temperature and swimming exercise on plasma $\mathrm{K}^{+} 21$ concentration. Plasma electrolytes data are shown in Table 3.

\subsection{Fluid balance}

Plasma volume increased (Fig. 2A) and the red cell volume decreased (Fig. 2B) at the end of all three conditions; however, percentage changes of plasma volume did not differ between trials. The red cell volume decreased the least in the $27^{\circ} \mathrm{C}$ trial than in the $32^{\circ} \mathrm{C}$ one $(P<0.05)$.

\subsection{Performance time}

In the $27^{\circ} \mathrm{C}$ trial was recorded the best chronometric time $(75.7 \pm 8.2 \mathrm{~min})$ and split time average $(1.51 \pm 0.2 \mathrm{~min})$, and the difference with the 23 and $32^{\circ} \mathrm{C}$ trials (chronometric time $79.7 \pm 11.0 \mathrm{~min}$ and $78.5 \pm 8.7 \mathrm{~min}$ respectively; split time average $1.59 \pm 0.2 \mathrm{~min}$ and $1.57 \pm 0.2 \mathrm{~min}$ respectively) was significant $(P<0.05)$, but an ordering effect on performance time cannot be excluded.

Table 2 Rectal and axillary temperature.

\begin{tabular}{|c|c|c|c|c|c|c|c|}
\hline & \multicolumn{2}{|l|}{$23^{\circ} \mathrm{C}$} & \multicolumn{2}{|l|}{$27^{\circ} \mathrm{C}$} & \multicolumn{2}{|l|}{$32^{\circ} \mathrm{C}$} & \multirow{2}{*}{$\frac{\text { Two-way ANOVA }}{P \text { value }}$} \\
\hline & Pre & Post & Pre & Post & Pre & Post & \\
\hline $\mathrm{T}_{\text {re }}\left({ }^{\circ} \mathrm{C}\right)$ & $37.1 \pm 0.3$ & $37.2 \pm 0.6$ & $37.0 \pm 0.3$ & $37.9 \pm 0.5^{a}$ & $36.9 \pm 0.4$ & $38.0 \pm 0.4^{a}$ & 0.0001 \\
\hline $\mathrm{T}_{\mathrm{ax}}\left({ }^{\circ} \mathrm{C}\right)$ & $36.2 \pm 0.5$ & $36.0 \pm 0.6$ & $36.2 \pm 0.3$ & $36.3 \pm 0.3$ & $36.3 \pm 0.3$ & $36.8 \pm 0.3^{b}$ & 0.0022 \\
\hline
\end{tabular}

The values are expressed as means $\pm \mathrm{SD}$. $\mathrm{T}_{\mathrm{re}}\left({ }^{\circ} \mathrm{C}\right)$ : rectal temperature; $\mathrm{T}_{\mathrm{ax}}\left({ }^{\circ} \mathrm{C}\right)$ : axillary temperature; $23^{\circ} \mathrm{C}$ : trial with the water at

$23^{\circ} \mathrm{C} ; 27^{\circ} \mathrm{C}$ : water at $27^{\circ} \mathrm{C}$; $32^{\circ} \mathrm{C}$ : water at $32^{\circ} \mathrm{C}$; Pre: before the trial; Post: after the trial.

a Significantly higher than other $\mathrm{T}_{\mathrm{re}}(P<0.05)$.

b Significantly higher than other $\mathrm{T}_{\mathrm{ax}}(P<0.05)$. 
Table 3 Serum electrolytes.

\begin{tabular}{|c|c|c|c|c|c|c|c|}
\hline & \multicolumn{2}{|l|}{$23^{\circ} \mathrm{C}$} & \multicolumn{2}{|l|}{$27^{\circ} \mathrm{C}$} & \multicolumn{2}{|l|}{$32^{\circ} \mathrm{C}$} & \multirow{2}{*}{$\frac{\text { Two-way ANOVA }}{P \text { value }}$} \\
\hline & Pre & Post & Pre & Post & Pre & Post & \\
\hline $\mathrm{Na}^{+}(\mathrm{mmol} / \mathrm{L})$ & $141.0 \pm 1.4^{d}$ & $141.0 \pm 1.6^{d}$ & $136.7 \pm 2.2$ & $138.5 \pm 2.7$ & $141.2 \pm 1.8^{d}$ & $144.3 \pm 1.0^{c}$ & 0.0469 \\
\hline $\mathrm{K}^{+}(\mathrm{mmol} / \mathrm{L})^{\mathrm{a}, \mathrm{b}}$ & $3.8 \pm 0.3$ & $4.1 \pm 0.4$ & $4.1 \pm 0.3$ & $4.4 \pm 0.3$ & $4.1 \pm 0.3$ & $4.3 \pm 0.3$ & $>0.05$ \\
\hline $\mathrm{Mg}^{++}(\mathrm{mmol} / \mathrm{L})^{\mathrm{b}}$ & $1.9 \pm 0.1$ & $1.7 \pm 0.1$ & $1.9 \pm 0.1$ & $1.6 \pm 0.1$ & $1.9 \pm 0.1$ & $1.7 \pm 0.1$ & $>0.05$ \\
\hline \multicolumn{8}{|c|}{$\begin{array}{l}\text { The values are expressed as means } \pm \mathrm{SD} \text {. Na+: sodium; } \mathrm{K}+\text { : potassium; } \mathrm{Mg}^{++}: \text {magnesium; } 23^{\circ} \mathrm{C} \text { : trial with the water at } 23^{\circ} \mathrm{C} ; 27^{\circ} \mathrm{C}: \text { water } \\
\text { at } 27^{\circ} \mathrm{C} ; 32^{\circ} \mathrm{C} \text { : water at } 32^{\circ} \mathrm{C} \text {; Pre: before the trial; Post: after the trial. } \\
\text { a Significant water temperature main effect from two-way ANOVA }(P=0.0150) \text {. } \\
\text { b Significant swimming exercise main effect from two-way ANOVA }(P=0.0001) \text {. } \\
\text { c Significantly higher than other } \mathrm{Na}^{+} \text {concentration }(P<0.05) \text {. } \\
\text { d Significantly higher than Pre and Post } 27^{\circ} \mathrm{C}(P<0.05) \text {. }\end{array}$} \\
\hline
\end{tabular}

\section{Discussion}

The aim of this study was to evaluate the physiological responses (dehydration, sweat rate, urine output, rectal temperature, plasma electrolytes and fluid balance) induced by a 5-km "simulated" race performed at different water temperatures in an indoor swimming pool.

To date, limited research has been conducted on hydration status during prolonged swimming training, and, to our knowledge, no study ever investigated the hydration status of swimmers after an open water event, although several general articles have outlined optimal fluid intake for swimmers [8]. The reason for the limited number of research on hydration status of swimmers during competition or training is the difficulty to control sweat loss. The sources of errors, detailed described by Cox et al. [8], are: failure to account for water absorbed through the skin, failure to account for water accidentally swallowed from the pool, failure to
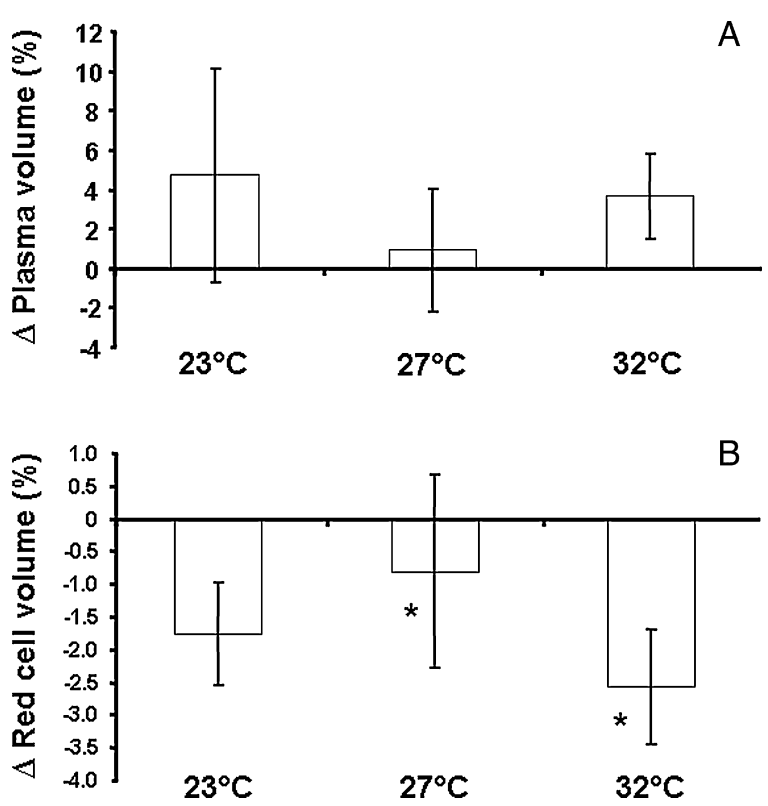

Figure 2 Fluid balance: changes in plasma (A) and red cell (B) volume in response to water temperature. The values are expressed as means \pm SD. Differences between data sets with the same symbol are significant $(P<0.05)$. account for respiratory losses, and failure to account for all urine losses.

Sweat rate during water sports is related to exercise intensity, core temperature and water temperature [8,9]. In our study, the athletes swam the $5 \mathrm{~km}$ of each trial at their personal highest intensity, as they would in a race, although the best performance was recorded during the $27^{\circ} \mathrm{C}$ trial, confirming the results in literature [15]. Therefore, the difference recorded in the sweat rate and in the body (axillary and rectal) temperature are purported to be induced exclusively by the water temperature, although, we acknowledge that axillary and rectal temperature measured with traditional mercury thermometers may have some limitations [11].

The $23^{\circ} \mathrm{C}$ water, during swimming at high intensity, was a thermoneutral environment because of slow sweat rate $(0.48 \mathrm{~L} / \mathrm{h})$ that did not raise body temperature inducing light dehydration $(0.9 \%,-0.65 \mathrm{~kg})$. The $32^{\circ} \mathrm{C}$ water increased the axillary and rectal temperatures, the $27^{\circ} \mathrm{C}$ trial increased the rectal temperature only, confirming results in literature, which showed that the increasing temperature of water combined with exercise intensity induces a rise of core and rectal temperatures [5-7]. None of the subjects were affected by hypothermia at the end of the three trials, although it is common in swimmers competing in an open water swimming event [2,3,16-18]. Thereby, the 27 and $32{ }^{\circ} \mathrm{C}$ water induced a fast sweat rate $(0.76 \mathrm{~L} / \mathrm{h}$ and $1.25 \mathrm{~L} / \mathrm{h}$ respectively) that compromised the hydration status of swimmers $(-1.3 \%,-0.94 \mathrm{~kg}$ and $-2.2 \%,-1.60 \mathrm{~kg}$, respectively). These results show that dehydration can occur rapidly in swimmers that compete in a $5-\mathrm{km}$ race in $32^{\circ} \mathrm{C}$ water and slower in colder water. These results are in contrast with the data of several articles, recorded during swimming training in $27^{\circ} \mathrm{C}$ water. Lemon et al. [18] observed that an interval swim training of $62 \mathrm{~min}$, without fluid intake, produced a body weight reduction of $0.6 \mathrm{~kg}$ and a sweat rate of $0.48 \mathrm{~L} / \mathrm{h}$. These results were corrected for weight gain due to uptake of water by the skin and for respiratory and metabolic losses. A similar body weight reduction $(0.7 \mathrm{~kg})$ is reported by Reaburn et al. [19] after a 4.7-km training session with no fluid intake. The lowest results are reported by Cox et al. [8], Maughan et al. [20] and Soler et al. [9] $(-0.11 \%, 0.41 \mathrm{~L} / \mathrm{h} ; 0.3 \%, 0.33 \mathrm{~L} / \mathrm{h}$ and $0 \%, 0.37 \mathrm{~L} / \mathrm{h}$, respectively), although the training sessions were longer and the swimmers drank ad libitum. Similar sweat rate $(1.07 \mathrm{~L} / \mathrm{hr})$ at $33^{\circ} \mathrm{C}$ water were found in a study of Robinson and Somers 
[21], although it was carried out only on two subjects, olympic-medal-winning swimmers, during a $60-\mathrm{min}$ freestyle training session at a high speed of about $1.2 \mathrm{~m} / \mathrm{s}$.

It is widely accepted that plasma aldosterone levels are linearly related to exercise intensity and heat exposure [22] and, even if hormone concentration was not tested during this study, we suppose that water loss and hyperosmolality induced by swimming in hot water would stimulate aldosterone secretion. Aldosterone in turn increases $\mathrm{Na}^{+}$uptake and consequently water retention in the distal tubules of nephrons. Our theory is confirmed by the data recorded: the Post urine output in the 27 and $32{ }^{\circ} \mathrm{C}$ trials, were more concentrated than in the $23^{\circ} \mathrm{C}$ ones, in fact, both the warm trials induced lower urine volume, higher USG concentration than in the $23^{\circ} \mathrm{C}$ trial. Furthermore, sodium and water re-absorption, stimulated by exercise in all three conditions, determined hypernatremia and hypervolemia, i.e. an increasing of plasma sodium concentration and an expanding of extracellular water. In fact, the percentage change of plasma volume increased in all three trials and the percentage change of red cell volume decreased in all three water conditions, showing the fluid shift from the intracellular space to the extracellular space to prevent the decline in plasma volume induced by the dehydration [23]. We acknowledge that USG is normally used as an indicator of longitudinal hydration status during chronic studies, and it may have some limitation to hydration status in an acute study [24]. Although, the plasma volume change has been already investigated in swimmers with the method of Dill and Costill [13] by Soler et al. [9], this technique should have a limitation related to equilibration period used before the blood draw. In this study, an equilibration period of $15 \mathrm{~min}$ was used to minimize the error source, while, Soler et al. [9] did not used an equilibration period before drawing the blood.

Our study provides unique information on the effects induced by water temperature during an open water swimming race on sweat rate and dehydration percentage, because this study is the first study conducted for open water swimmers during swimming, and not during under water exercise, at race intensity [19]. The results of this study show that during the shortest open water swimming event distance $(5 \mathrm{~km})$ performed at race intensity: (i) the dehydration and the sweat rate incurred in $27^{\circ} \mathrm{C}$ water are greater than that reported in swimming-training studies; (ii) the dehydration and the sweat rate and body temperatures simultaneously increase with the rise of water temperature.

\section{Conflict of interest statement}

None.

\section{Acknowledgments}

We thank the athletes who participated in the study and the coach Salvo Caleca for help in data collection. We thank Mrs M. Moyen and A.W. Isaacs (Department of Physiological Science, Stellenbosch University, South Africa) for reading and commenting on our paper.

\section{References}

[1] http://www. fina.org.

[2] Gerrard DF. Open water swimming. Particular medical problems. Clin Sports Med 1999;18(2):337-47.

[3] Castro RR, Mendes FS, Nobrega AC. Risk of hypothermia in a new Olympic event: the $10-\mathrm{km}$ marathon swim. Clinics (Sao Paulo) 2009;64(4):351-6.

[4] Miller JW. Injuries and considerations in masters aquatics sports. Clin Sports Med 1999;18(2):413-26.

[5] Costill DL, Cahill PJ, Eddy D. Metabolic responses to submaximal exercise in three water temperatures. J Appl Physiol 1967;22(94):628-32.

[6] Galbo H, Houston ME, Christensen NJ, Holst JJ, Nielsen B, Nygaard E, et al. The effect of water temperature on the hormonal response to prolonged swimming. Acta Physiol Scand 1979;105(3):326-37.

[7] Craig AB, Dvorak M. Thermal regulation of man exercising during water immersion. J Appl Physiol 1968;25(1):28-35.

[8] Cox GR, Broad EM, Riley MD, Burke LM. Body mass changes and voluntary fluid intakes of elite level water polo players and swimmers. J Sci Med Sport 2002;5(3):183-93.

[9] Soler R, Echegaray M, Rivera MA. Thermal responses and body fluid balance of competitive male swimmers during a training session. J Strength Cond Res 2003;17(2):362-7.

[10] Bonsignore MR, Morici G, Riccobono L, Profita M, Bonanno A, Paternò A, et al. Airway cells after swimming outdoors or in the sea in nonasthmatic athletes. Med Sci Sports Exerc 2003;35(7):1146-52.

[11] Casa DJ, Becker SM, Ganio MS, Brown CM, Yeargin SW, Roti $M W$, et al. Validity of devices that assess body temperature during outdoor exercise in the heat. J Athl Train 2007;42(3): $333-42$.

[12] Sund-Levander M, Grodzinsky E, Loyd D, Wahren LK. Errors in body temperature assessment related to individual variation, measuring technique and equipment. Int $\mathrm{J}$ Nurs Pract 2004;10(5):216-23.

[13] Dill DB, Costill DL. Calculation of percentage changes in volumes of blood, plasma, and red cells in dehydration. J Appl Physiol 1974;37(2):247-8.

[14] Godek SF, Bartolozzi AR, Burkholder R, Sugarman E, Peduzzi C. Sweat rates and fluid turnover in professional football players: a comparison of National Football League linemen and backs. J Athl Train 2008;43(2):184-9.

[15] Mougios V, Deligiannis A. Effect of water temperature on performance, lactate production and heart rate at swimming of maximal and submaximal intensity. J Sports Med Phys Fitness 1993;33(1):27-33.

[16] Brannigan D, Rogers IR, Jacobs I, Montgomery A, Williams A, Khangure N. Hypothermia is a significant medical risk of mass participation long-distance open water swimming. Wilderness Environ Med 2009;20(1):14-8.

[17] Mountjoy M, Junge A, Alonso JM, Engebretsen L, Dragan I, Gerrard D, et al. Sports injuries and illnesses in the 2009 FINA World Championships (Aquatics). Br J Sports Med 2010;44(7): 522-7.

[18] Lemon PW, Deutsch DT, Payne WR. Urea production during prolonged swimming. J Sports Sci 1989;7(3):241-6.

[19] Reaburn P, Pearce S, Starr-Thomas G. Fluid loss in swimmers. J Swimming Res 1996;11:36-9.

[20] Maughan RJ, Dargavel LA, Hares R, Shirreffs SM. Water and salt balance of well-trained swimmers in training. Int J Sport Nutr Exerc Metab 2009;19(6):598-606.

[21] Robinson S, Somers A. Temperature regulation in swimming. J Physiol (Paris) 1971;63(3):406-9.

[22] Sawka MN, Burke LM, Eichner ER, Maughan RJ, Montain SJ, Stachenfeld NS. American College of Sports Medicine position 
stand. Exercise and fluid replacement. Med Sci Sports Exerc 2007;39(2):377-90.

[23] Tipton CM. ACSM's advanced exercise physiology. United States of America: Lippincott Williams \& Wilkins; 2005.
[24] Decher NR, Casa DJ, Yeargin SW, Ganio MS, Levreault ML, Dann $\mathrm{CL}$, et al. Hydration status, knowledge, and behavior in youths at summer sports camps. Int J Sports Physiol Perform 2008;3(3):262-78. 